\title{
PRICKLE1 wt Allele
}

National Cancer Institute

\section{Source}

National Cancer Institute. PRICKLE1 wt Allele. NCI Thesaurus. Code C126759.

Human PRICKLE1 wild-type allele is located in the vicinity of $12 q 12$ and is approximately $134 \mathrm{~kb}$ in length. This allele, which encodes prickle-like protein 1, plays a role in the negative regulation of Wnt signaling and in embryonic development. Mutation of the gene is associated with progressive myoclonic epilepsy 1B. 